\title{
Assessment of thyroid and prolactin levels among the women with abnormal uterine bleeding
}

\author{
Jovita Deepthy John ${ }^{1 *}$, Vimala Damodaran ${ }^{1}$, Shankar Radhakrishnan ${ }^{2}$
}

\begin{abstract}
${ }^{1}$ Department of Obstetrics and Gynecology, ${ }^{2}$ Department of Preventive Medicine, Vinayaka Missions Kirupananda Variyar Medical College, Salem, Tamil Nadu, India
\end{abstract}

Received: 04 April 2017

Accepted: 02 May 2017

\author{
*Correspondence: \\ Dr. Jovita Deepthy John, \\ E-mail: jovithadeepthy@gmail.com
}

Copyright: (c) the author(s), publisher and licensee Medip Academy. This is an open-access article distributed under the terms of the Creative Commons Attribution Non-Commercial License, which permits unrestricted non-commercial use, distribution, and reproduction in any medium, provided the original work is properly cited.

\begin{abstract}
Background: Thyroid disorders are 10 times more common in women than men.1 Menstrual disturbances usually accompany clinical alterations in thyroid function and every clinician would have encountered altered menstrual pattern among women suffering from either hypo or hyper thyroidism. A high serum prolactin level can distrurb the follicular maturation and corpus luteum function, and leads to inhibition of normal pulsatile secretion of gonadotrophin-releasing hormone in hypothalamus resulting in anovulation. The aim of the study was to assess the thyroid and the prolactin levels among the women with abnormal uterine bleeding and to evaluate the association between them by comparing with normal females.

Methods: A cross sectional study was conducted for a period of one year between Jan 2016 and December 2016 in our institution at the gynaecology OPD. Patients in the age group of 15 to 45 with the complaints of abnormal uterine bleeding and with the ultrasound findings showing normal uterus and ovary were included in the study. Hundred age and sex matched controls without any complaints of abnormal uterine bleeding in the age group of 15 - 45 years were also included in the study. Free T3, Free T4, TSH and prolactin estimation was done by chemiluminescent immunoassay for both the patients and the controls.

Results: The mean TSH levels among the cases were much higher than that of the controls and the difference in the levels found to be statistically significant. Similarly, hyperprolactinemia was found in 18 cases when compared to 2 cases in controls and the mean prolactin levels were higher in cases. The serum prolactin levels and the serum TSH levels showed a perfect positive correlation which indicates that as the TSH level increases prolactin levels also increases with the $\mathrm{R}$ value $>0.5$.

Conclusions: Early detection of hypothyroidism in such subjects saves the patient from recurrent curettage and at times hysterectomy. The financial implications of screening for prolactin/thyroid hormone abnormalities will have to be evaluated before a general recommendation can be made.
\end{abstract}

Keywords: AUB, Prolactin, Thyroid function test

\section{INTRODUCTION}

Thyroid disorders are 10 times more common in women than men. ${ }^{1}$ Menstrual disturbances usually accompany clinical alterations in thyroid function and every clinician would have encountered altered menstrual pattern among women suffering from either hypo or hyper thyroidism.
Hypothyroidism commonly causes menorrhagia. Hyperthyroidism is associated with menorrhagia followed by oligomenorrhoea and amenorrhoea proportionate to the severity of thyrotoxicosis..$^{2,3}$

Abnormal uterine bleeding occurs due to any disruption in the normal physiology or anatomic changes in the 
endometrium. ${ }^{4}$ Initially AUB was broadly divided in to two categories $\rightarrow$ ovulatory and anovulatory, but now after November 2010 the International Federation of Gynaecology and Obstetrics formally accepted a new classification system for causes of AUB in reproductive years. The system is based on acronym PALM-COEIN. PALM (Structural causes) $\rightarrow$ Polyps, Adenomyosis, Leiomyoma, Malignancy. COEIN (nonstructural causes) $\rightarrow$ Coagulopathy, Ovulatory disorders, Endometrial causes, Iatrogenic, not classified. ${ }^{5,6}$

Abnormality of menstruation is primarily a disorder of hypothalamo-pituitary-ovarian axis either through direct effect or indirectly by their effect on target organ. Endocrinological disturbances other than the reproductive hormones form a small but significant sub-group in the aetiopathogenesis of abnormal uterine bleeding. Amongst the endocrinological causes, after the pituitary, thyroid is probably the most important endocrine organ which exerts a broad range of effects on the development, growth, metabolism and function of virtually every organ system in the human body. ${ }^{7}$

Alterations in production and activity of the thyroid hormones thyroxine (T4) and tri-iodothyronine (T3) may result in menstrual abnormality. Both hyperthyroidism and hypothyroidism may result in menstrual disturbances. ${ }^{8}$ The mechanism of menorrhagia in hypothyroidism is incompletely understood. It is postulated that infrequent or absent ovulation leads to deficient secretion of luteinizing hormone which may result in relative oestrogen excess thereby causing menorrhagia.

There may be episodes of amenorhoea interspersed with periods of heavy vaginal bleeding also. Various studies have reported that there are changes in cycle length, amount and duration of bleeding associated with thyroid disorders. Sometimes they may also present with infertility, recurrent pregnancy losses and galactorrhoea. ${ }^{9,10}$

Studies showed that $33.3 \%$ patients with hypothyroidism had menorrhagia. The mechanism explained was it seems that poor progesterone production is associated with persistent endometrial proliferation which may be responsible for massive bleeding (anovulatory bleeding). Another, mechanism for this may be failure of $\mathrm{LH}$ secretion. $44.4 \%$ patients with hypothyroidism had oligomenorrhoea. This was explained by the galactorrhoea-amenorrhoea syndrome in long standing hypothyroid patients. ${ }^{1}$

Hyperthyroidism occurring before puberty has been reported to delay the onset of menses. In women of fertile age group, oligomenorrhea and amenorrhea are the commonest abnormalities associated with hyperthyroidism. ${ }^{11}$ These irregularities sometimes precede thyroid dysfunction. In the present times, subclinical hyper- and hypothyroidism can be diagnosed very early, whereas these would have passed unnoticed a few decades ago. Timely detection of Thyroid disorder in patients presenting with menstrual disorders and their management can prevent surgical intervention like curettage and hysterectomy. Thyroid autoimmunity has been shown to have association with various kinds of thyroid dysfunction.

A high serum prolactin level can distrurb the follicular maturation and corpus luteum function, and leads to inhibition of normal pulsatile secretion of gonadotrophinreleasing hormone in hypothalamus. ${ }^{12}$ It also leads to deficient secretion of $\mathrm{LH}$ and FSH which leads to inadequate induction of proper ovarian response. ${ }^{13}$ As of today very few studies had been done to see the association of prolactin and thyroid levels among females with abnormal uterine bleeding, so the present study was aimed to assess these levels among women with AUB.

The aim of the study was to assess the thyroid and the prolactin levels among the women with abnormal uterine bleeding and to evaluate the association between them by comparing with normal females.

\section{METHODS}

A cross sectional study was conducted for a period of one year between Jan 2016 and December 2016 in our institution at the gynaecology OPD. Patients in the age group of 15 to 45 with the complaints of abnormal uterine bleeding and with the ultrasound findings showing normal uterus and ovary were included in the study. Patients with any form of uterine and thyroid abnormalities, patients who are on hormonal drugs or steroids, IUCD users, history of bleeding disorders (hemophilia, von Willebrand's disease) and pelvic infections including endometritis, PID, PCOD were excluded from the study.

A total of hundred patients who were fitting into the above criteria were included in the study. Hundred age and sex matched controls without any complaints of abnormal uterine bleeding in the age group of 15-45 years were also included in the study.

A detailed history related to onset, duration, interval and amount of bleeding was obtained from the patients. Both the patients and the controls were subjected to routine investigations like blood counts, urine examination for sugar, albumin and microscopy, bleeding time and clotting time to rule out coagulation defect and ultrasound to rule out uterine or ovarian pathologies. Free T3, Free T4, TSH and prolactin estimation was done by chemiluminescent immunoassay for both the patients and the controls. Based on the thyroid levels patients were grouped into euthyroid, subclinical hypothyroid, hypothyroid and hyperthyroid and based on the prolactin levels they were classified as normal prolactin and hyperprolactinemia. The data were analyzed by using SPSS version 20. The sociodemographic data was analysed by simple proportions and percentages. The association and relation between different parameters were analyzed using chi-square test and pearson's correlation test. 


\section{RESULTS}

Table 1: Age wise distribution of the study population.

\begin{tabular}{|c|c|c|c|}
\hline Age group & Cases & Controls & P value \\
\hline$<15$ & 2 & 3 & \multirow{7}{*}{0.738} \\
\hline $15-25$ & 20 & 18 & \\
\hline $26-35$ & 29 & 30 & \\
\hline $36-45$ & 48 & 46 & \\
\hline$>45$ & 1 & 3 & \\
\hline Total & 100 & 100 & \\
\hline Mean \pm SD & $33.8 \pm 8.3$ & $34.2 \pm 7.4$ & \\
\hline
\end{tabular}

Table 1 shows the age wise distribution among the cases and controls. It is seen from the Table that majority of the women were in the age group of between 25 and 45 years in both the groups with the mean age of 33.8 years among cases and 34.2 years among the controls and it proves that the age was completely matched for selecting the controls. The various gynaecological symptoms with which the cases were presented to our department were shown in Table 2.

Table 2: Distribution of the cases based on their symptoms.

\begin{tabular}{|lll|}
\hline Symptoms & Frequency & $\%$ \\
\hline Amenorrhea & 2 & 2.0 \\
\hline Menorrhagia & 42 & 42.0 \\
\hline Oligomenorrhoea & 38 & 38.0 \\
\hline Polymenorrhagia & 17 & 17.0 \\
\hline MetropathiaHaemorrhagica & 1 & 1.0 \\
\hline Total & 100 & 100.0 \\
\hline
\end{tabular}

Menorrhagia was found to be the most common symptom among the patients with abnormal uterine bleeding (AUB) followed by oligomenorrhoea and polymenorrhagia.

Speculum examination was done for all the patients in the case group and among them 64 of them had normal cervix and 16 of them had eroded and 9 of them had hypertrophied cervix (Table 3).

Table 3: Distribution of the cases based on them per speculum findings.

\begin{tabular}{|lll|}
\hline Per speculum findings & Frequency & $\%$ \\
\hline Cervix normal & 64 & 64 \\
\hline Cervix erosion & 16 & 16 \\
\hline Cervix hypertrophied & 9 & 9 \\
\hline Cervix flushed with vagina & 6 & 6 \\
\hline Cervix- Nabothian cyst & 5 & 5 \\
\hline Total & 100 & 100 \\
\hline
\end{tabular}

The ultrasound abdomen which was performed on all cases showed bulky uterus for 9 patients and atrophied uterus in 3 patients and for remaining it was normal. The haemoglobin levels were assessed among both the cases and controls and it was found to be much lower in cases than the controls.

The mean $\mathrm{Hb}$ among cases was $9.4 \mathrm{gms} / \mathrm{dl}$ and among controls it was $11.6 \mathrm{gm} / \mathrm{dl}$ and the difference between them was found to be statistically significant $(\mathrm{p}<0.05)$ (Table 4).

Table 4: Comparison of haemoglobin levels among cases and controls.

\begin{tabular}{|llll|}
\hline Hb levels (gms/dl) & Cases & Controls & P value \\
\hline$<8$ & 11 & 3 & \\
\hline $8-12$ & 85 & 60 & \\
\hline $12-14$ & 4 & 24 & \\
\hline$>14$ & 0 & 13 & $<0.005$ \\
\hline Total & 100 & 100 & \\
\hline Mean \pm SD $(\mathrm{gms} / \mathrm{dl})$ & $9.4 \pm 1.2$ & $11.6 \pm 2.4$ & $<0.005$ \\
\hline
\end{tabular}

This proves that abnormal uterine bleeding has a significant impact on the haemoglobin levels. The thyroid function was assessed by measuring the free $\mathrm{T} 3$, free $\mathrm{T} 4$ and TSH levels among both the cases and controls.

Table 5: Comparison of levels of thyroid function test among cases and controls.

\begin{tabular}{|c|c|c|c|c|}
\hline \multicolumn{2}{|c|}{$\begin{array}{l}\text { Thyroid function } \\
\text { test }\end{array}$} & Cases & Controls & $\begin{array}{l}P \\
\text { value }\end{array}$ \\
\hline \multirow{4}{*}{$\begin{array}{l}\text { Free T3 } \\
(\mathrm{pg} / \mathrm{ml})\end{array}$} & $<2.1$ & 37 & 16 & \multirow{3}{*}{$<.001$} \\
\hline & $2.1-4.4$ & 61 & 83 & \\
\hline & $>4.4$ & 2 & 1 & \\
\hline & Mean \pm SD & $1.87 \pm 2.1$ & $2.38 \pm 3.3$ & $<.001$ \\
\hline \multirow{4}{*}{$\begin{array}{l}\text { Free T4 } \\
(\mathrm{ng} / \mathrm{dl})\end{array}$} & $<0.8$ & 37 & 17 & \multirow{3}{*}{$<.001$} \\
\hline & $0.8-2.7$ & 60 & 82 & \\
\hline & $>2.7$ & 3 & 1 & \\
\hline & Mean \pm SD & $1.08 \pm 0.98$ & $1.34 \pm 1.02$ & $<.001$ \\
\hline \multirow{4}{*}{$\begin{array}{l}\text { TSH } \\
(\mu \mathrm{IU} / \mathrm{ml})\end{array}$} & $<0.35$ & 2 & 3 & \multirow{3}{*}{$<.001$} \\
\hline & $0.35-5.5$ & 42 & 75 & \\
\hline & $>5.5$ & 56 & 22 & \\
\hline & Mean \pm SD & $8.34 \pm 4.8$ & $4.32 \pm 3.7$ & $<.001$ \\
\hline
\end{tabular}

Table 6: Comparison of prolactin levels among cases and controls.

\begin{tabular}{|llll|}
\hline Prolactin levels & Cases & Controls & P value \\
$\begin{array}{l}\text { Hyperprolactenemia } \\
\text { (Prl }>1.3 \mathrm{nmol} / \mathrm{l})\end{array}$ & 18 & 2 & \\
\hline $\begin{array}{l}\text { Normal prolactin } \\
\text { levels }(<1.3 \mathrm{nmol} / \mathrm{l})\end{array}$ & 78 & 98 & $<.001$ \\
\hline Mean $\pm \mathrm{SD}(\mathrm{ngm} / \mathrm{ml})$ & $27.8 \pm 2.5$ & $12.3 \pm 2.8$ & $<.001$ \\
\hline
\end{tabular}

TSH levels of more than $5.5 \mu \mathrm{IU} / \mathrm{ml}$ was considered as hypothyroidism and among the cases 56 of them and among controls 22 of them had hypothyroidism and the difference found to be statistically significant. Similarly, the mean levels of free T3, T4 and TSH showed a statistically significant difference among the cases and 
controls (Table 5). Serum prolactin levels were measured among the cases and controls. Prolactin levels of more than $1.3 \mathrm{nmol} / \mathrm{l}$ was considered as hyperprolactenemia and among cases 18 and among controls 2 of them had hyperprolactenemia and the mean prolactin levels among the cases was $27.8 \mathrm{ngm} / \mathrm{ml}$ and among the controls it was
$12.3 \mathrm{ngm} / \mathrm{ml}$ and the difference was found to be statistically significant $(\mathrm{p}<0.05)$ (Table 6). The serum prolactin levels and the serum TSH levels showed a perfect positive correlation which indicates that as the TSH level increases prolactin levels also increases with the $\mathrm{R}$ value $>0.5$ (Table 7).

Table 7: Pearsons correlation between TSH and serum prolactin levels.

\begin{tabular}{|c|c|c|c|c|c|}
\hline Cases & & $\mathbf{R}$ value & Controls & & $\mathbf{R}$ value \\
\hline $\begin{array}{l}\text { Mean TSH levels } \\
(\mu \mathrm{IU} / \mathrm{ml})\end{array}$ & $\begin{array}{l}\text { Mean prolactin } \\
\text { levels (ngm/ml) }\end{array}$ & & $\begin{array}{l}\text { Mean TSH levels } \\
(\mu \mathrm{IU} / \mathrm{ml})\end{array}$ & $\begin{array}{l}\text { Mean prolactin levels } \\
(\mathrm{ngm} / \mathrm{ml})\end{array}$ & \\
\hline 8.34 & 27.8 & 0.845 & 4.32 & 12.3 & 0.636 \\
\hline
\end{tabular}

\section{DISCUSSION}

In the present study majority of the study subjects were in the age group between 25-45 years and it is almost in par with the studies done by Narula et al, Pahwa $\mathrm{S}$ et al and Kumar A et al. ${ }^{14-16}$

In our study majority of the women were multiparous and only $5 \%$ were nulliparous and it was almost similar to the findings quoted by Pilli etal. ${ }^{17}$ Menorrhagia is a frequent debilitating symptom in gynaecological practice resulting in need for repeated curettage and hysterectomy with its attendant morbidity and mortality.

Objective measurements have shown that mean menstrual blood loss in each menstrual cycle is $35 \mathrm{ml}$ and menstrual blood loss is considered to be excessive when it is more than $80 \mathrm{ml}$ per cycle (90th percentile). ${ }^{18}$

In our study, we found menorrhagia to be the most common symptom (42\%) among abnormal uterine bleeding and it is in par with the study done by Kumar A et al.

The present study had shown the prevalence of hypothyroidism and subclinical hypothyroidism was $56 \%$ among the patients with abnormal uterine bleeding and our results almost matches the results quoted by Doifode et al, Douglas et al, Singh L et al and Shruthi et al and in all those studies they had also shown that menorrhagia as the most common symptom in patients with hypothyroidism or subclinical hypothyroidism. ${ }^{19-22}$

One of the explanations is the activity of thyroid is that closely linked with the process of ovarian maturation. The thyroid gland is itself dependent on direct and indirect stimulation from the ovary to discharge its own function.

Previous studies have evaluated the prevalence of hyperprolactinemia among patients with menstruation related problems in which most of these studies included patients with oligomenorrhea or amenorrhea. For example,
Lee et al studied hyperprolactinemia in adolescents and young women with menstrual problems. ${ }^{23}$ They divided the study population in two groups based on age and found a $9.4 \%$ prevalence of hyperprolactinemia in the group aged 21-30 years compared with a $2.4 \%$ prevalence in the group aged 11-20 years. In other studies, the prevalence of hyperprolactinemia varied from approximately $0.2 \%$ in an unselected normal adult population to $15 \%-20 \%$ among women with reproductive disorders, whereas a study of women with a wider age range (15-45 years) found that $61 \%$ of patients with abnormal bleeding had hyperprolactinemia, whereas in our study only $18 \%$ of patients with abnormal uterine bleeding had hyperprolactenemia and $2 \%$ of women without abnormal uterine bleeding had hyperprolactenemia. ${ }^{24-26}$

Most of thegynaecologists today will investigate for prolactin levels only among patientswith symptoms of galactorrhea or galactorrhea associated with oligomenorrhea or amenorrhea. In the current study, galactorrhea was present in $18 \%$ of the patients with AUB overall. ${ }^{27}$ Thus, if prolactin levels are only measured in patients with galactorrhea, hyperprolactinemia will be missed in a considerable number of patients.

The association between thyroid disturbances and hyperprolactinemia has long been postulated, although some studies have not find any correlation between prolactin and thyroid hormones. ${ }^{28}$

In people, TSH and prolactin secretion is controlled by an interrelated pathway. If a common regulatory mechanism is involved, the pituitary thyrotrophs and lactotrophs have shown differential sensitivity to the common stimulatory and inhibitory substances. ${ }^{29}$

In the current study, the association between elevated prolactin levels and abnormal TSH was evident by showing a perfect positive correlation between TSH levels and serum prolactin levels, indicating that the menstrual cycle is affected via a common pathway. 


\section{CONCLUSION}

With the advent of modern hormonal assay techniques precise estimation of thyroid hormones in serum is possible in a rapid and reliable manner. Treatment of hypothyroidism is very satisfying as it usually relieves patient of all the symptoms.

Hence in investigating a patient with menorrhagia and/or menstrual irregularities, evaluation of thyroid functional status forms an essential component. Early detection of hypothyroidism in such subjects saves the patient from surgical interventions like curettage and hysterectomy.

The financial implications of screening for prolactin/thyroid hormone abnormalities will have to be evaluated before a general recommendation can be made.

\section{Funding: No funding sources}

Conflict of interest: None declared

Ethical approval: The study was approved by the Institutional Ethics Committee

\section{REFERENCES}

1. Mazzaferri EL. Evaluation and management of common thyroid disorders in women American J Obstet Gynaecol. 1997;176(3):144-9.

2. Sharma N, Sharma A. Thyroid profile in menstrual disorders. JK Science. 2012;14(1):14-7.

3. Abraham R, Murugan VS, Pukazhvanthen P. Thyroid disorders in women of puducherry. Indian $\mathrm{J}$ Clin Biochem. 2009;24(1):52-9.

4. Steiner RA, Fink D. Abnormal menstrual bleeding. Schweiz Rundsch Med Prax. 2002;91:1967-74.

5. ACOG practice bulletin: management of anovulatory bleeding. Int J Gynaecol Obstet. 2001;72:263-71.

6. Nesse R. Abnormal vaginal bleeding in perimenopausal women. Am Family Physician. 1989;40:185.

7. Thomas R, Reid RL. Thyroid diseases and reproductive dysfunction. Obstet Gynaecol. 1987;70:789-98.

8. Mazzaferri EL. Evaluation and management of common thyroid disorders in women. Am J Obstet Gynaecol. 1997;176(3):144-9.

9. Kochupillai N. Clinical endocrinology in India. Curr Sci. 2000;79:1061-7.

10. Hollowell JG, Staehling NW, Flanders WD. Serum TSH, T4 and thyroid antibodies in the United States population (1988 to 1994): National health and nutrition examination survey (NHANES III). J Clin Endocrinol Metab. 2002;87(2):489-99.

11. Padmaleela K, Vimala T, Lavanya KM, Kiranmai D. Thyroid disordrs and dysfunctional uterine bleeding (DUB) among reproductive age group women. A cross sectional study in a tertiary care hospital in Andhra Pradesh, India. Int $\mathbf{J}$ Med Pharm Sci. 2013;4(1):41-6.
12. Nawroth F. Hyperprolactenemia and the regular menstrual cycle in asymptomatic women: should it be treated during treatment for infertility? Reprod Biomed Online. 2005;11(5):581-8.

13. Bragiota SI, Bonotis KS, Messinis IE, Angelpoulos NV. The effects of antipsychotics on prolactin levels and women's menstruation. Schizophr Res Treat. 2013:2013:502697.

14. Narula ER; Menstrual Irregularities. J Obstet Gynecol India. 1967;17:164.

15. Pahwa S, Gupta S, Kumar J. Thyroid dysfunction in dysfunctional uterine bleeding. J Adv Res Biol Sci. 2013;5(1):78-83.

16. Kumar AHS, Saravanan S. A study of prevalence of thyroid disorders in patients with abnormal uterine bleeding. Int J Reprod Contracept Obstet Gynecol. 2017;6(3):1036-9.

17. Pilli GS, Sethi B, Dhaded AV, Mathur PR. Dysfunctional uterine bleeding. J Obstet Gynecol India. 2001;52(3):87-9.

18. Deshmukh PY, Boricha BG, Pandey A. The association of thyroid disorders with abnormal uterine bleeding.Int J Reprod Contracept Obstet Gynecol. 2015;4(3):701-8.

19. Doifode CD, Fernandes K. Study of thyroid dysfunction in patients with dysfunctional uterine bleeding. J Obstet Gynecol India. 2001;51:93-5.

20. Singh L, Agarwal CG, Choudhary SR, Mehra P, Rajan Khare. Thyroid profile in infertile woman. J Obstet Gynecol India. 1990;40:248.

21. Wilansky DL, Grisesman B. Early hypothyroidism in patients with menorrhagia Am J Obstet and Gynaecol. 1990;163(2):697.

22. Sruthi T, Shivanna SB. Prevalence of hypothyroidism in patients with provisional diagnosis of DUB, $\mathrm{J}$ of Evolution of med and dental sciences. 2014;3(1):2967-72.

23. Lee DY, Oh YK, Yoon BK, Choi D. Prevalence of hyperprolactinemia in adolescents and young women with menstruation-related problems. Am J Obstet Gynecol. 2012;206(3):213.

24. Mah PM, Webster J. Hyperprolactinemia: etiology, diagnosis, and management. Semin Reprod Med 2002;20(4):365-74.

25. Serri O, Chik CL, Ur E, Ezzat S. Diagnosis and management of hyperprolactinemia. CMAJ. 2003;169(6):575-81

26. Eftekhari N, Mirzaei F, Karimi M. The prevalence of hyperprolactinemia and galac- torrhea in patients with abnormal uterine bleeding. Gynecol Endocrinol. 2008; 24(5):289-91.

27. Shin SY, Lee YY, Yang SY, Yoon BK, Bae D, Choi D. Characteristics of menstruation related problems for adolescents and premarital women in Korea. Eur J Obstet Gynecol Reprod Biol. 2005;121(2):236-42.

28. Raber W, Gessl A, Nowotny P, Vierhapper H. Hyperprolactinaemia in hypothyroid-ism: clinical significance and impact of TSH normalization. Clin Endocrinol (Oxf). 2003;58(2):185-91. 
29. Refetoff S, Fang VS, Rapoport B, Friesen HG. Interrelationships in the regulation of $\mathrm{TSH}$ and prolactin secretion in man: effects of L-dopa, TRH and thyroid hormone in various combinations. J Clin Endocrinol Metab. 1974;38(3):450-7.
Cite this article as: John JD, Damodaran V, Radhakrishnan S. Assessment of thyroid and prolactin levels among the women with abnormal uterine bleeding. Int J Reprod Contracept Obstet Gynecol 2017;6:2547-52. 